American sociologist Kathleen Shaputis labeled Millennials as the Peter Pan generation, because of their perceived tendency to delay some steps into adulthood (like housing, career and marriage) for longer periods than most generations before them. These labels were also a reference to a trend toward members living with their parents for longer. They're also the first generation of digital natives, and their affinity for technology helps shape how they shop. They are used to instant access to price comparisons, product information and peer reviews. Finally, they are dedicated to wellness, devoting time and money to exercising and eating right. Their active lifestyle influences trends in everything from food and drink to fashion.

They are the Yahoo, mobile phones, Google, Facebook, iPhone generation. With unlimited access to information, they tend to be assertive, with strong views. Envision the world as a $24 / 7$ place; want fast and immediate processing. Generation $Y$ are less brand loyal and the speed of the Internet made them flexible and changing in their fashion, style consciousness and where and how it is communicated with.

\section{Generation Z:}

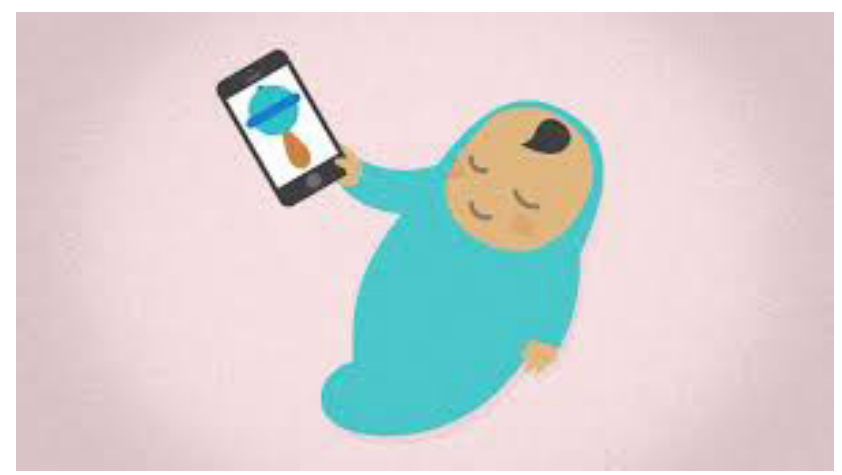

It is the generation born after 1995 and they have never known a world without computers and cell phones. They are digital integrators, having integrated technology seamlessly into their lives, and having used it from the youngest age; it is almost like the air that they breathe, permeating almost all areas of their lifestyle and relationships.
They are savvy consumers and they know what they want and how to get it and they are over saturated with brands.Globally focused, visually engaged, educationally transformed, socially defined. It is the generation that will experiment Google glass, nano-computing, 3D printing, driverless cars. Referred to as "Technoholics", because they are entirely dependent on IT.

б) виконання післятекстових завдань.

Task 1: Tell the rest of the class about the defining characteristics of the generation you've read about. As there are only 5 texts, some of you will start presenting the particular generation and the other will continue or add some of the missing details.

Режим роботи: S1- S2, S3-S4 і т.д.

Task 2. Read the questions and choose the one with a partner. You'll have 5 minutes to discuss this question in pairs. Tell the rest of the class what kind of conclusion you have arrived at.

Questions:

Do you see yourself as belonging to a particular generation? What characterizes this generation?

How do you think the generation born between 2000 and 2020 will be different?

Режим роботи: S1- S2, S3-S4 і т.д; T-S1-S3-S5 i т.д.

\section{5. Письмо}

Task: To sum up our discussion answer the question "Do you think there is such a thing as "the generation gap"? Write a paragraph explaining why. Use the vocabulary we have covered.

\section{6. Підведення підсумків заняття. Пояс- нення домашнього завдання.}

Today we've discussed different generations, specified their peculiarities and factors which shaped them.

\section{Оцінювання знань студентів.}

Your points for today are .... Thank you for coming and participating. See you next week.

Vitae:

Olha Drahinda, PhD in Translation Studies, Assistant Professor, Department of Teaching Methodology of Ukrainian and Foreign Languages and Literatures, Institute of Philology, Taras Shevchenko National University of Kyiv, Ukraine.

Area of research interests includes teaching English methodology and literary translation.

E-mail: olyadraginda@gmail.com. 


\section{РОЗРОБКА НАВЧАЛЬНОГО ЗАНЯТТЯ НА ТЕМУ «МРІЇ ТА РЕАЛЬНІСТЬ» 3 ДИСЦИПЛІНИ «ЗАГАЛЬНИЙ КУРС ЗАХІДНОЄВРОПЕЙСЬКОЇ МОВИ» ДЛЯ СТУДЕНТІВ ІІ КУРСУ СПЕЦІАЛЬНОСТІ «СХІДНА ФІЛОЛОГІЯ»}

\section{Тема заняття: DREAMS \& REALITY Цілі заняття: \\ Практичні:}

- опрацювати лексичний матеріал на тему мрії та реальність;

- розвивати вміння студентів розуміти на слух автентичне мовлення;

- розвивати вміння студентів читати та обговорювати додаткові тексти;

- активізувати уміння усного діалогічного та монологічного мовлення;

- розвивати вміння вести групову бесіди, дискусії та дебати за темою заняття;

- розвивати уміння студентів декламувати вірші.

\section{Освінні:}

- розширювати знання студентів щодо вимог публічного виступу, на прикладі промови видатного політичного діяча Мартіна Лютера Кінга “I Have A Dream", August 28, 1963;

- розвивати увагу, мовленнєву реакцію, фонематичний слух та пам'ять студентів;

- розширювати загальний і фрілологічний кругозір студентів;

- поглибити знання студентів шляхом інтерпретації цитат видатних англійських, американських та ірландських авторів щодо 'dreams'.

\section{Розвиваючі:}

- розвивати мовленнєві здібності студентів (фонематичний та інтонаційний слух, мовну здогадку, імітацію, логічний виклад думок тощо);

- розвивати уміння переносу знань та навичок студентів у нові ситуації мовлення на основі проблемно-пошукової діяльності;

- розвивати готовність студентів до подальшої самоосвіти.

- Виховні:

- виховувати почуття гордості за свою країну;

- виховувати культуру спілкування, прийнятну в сучасному цивілізованому світі;
- формувати критичне ставлення до вчинків людей;

- виховувати ціннісні орієнтації, почуття та емоції;

- виховувати такі риси характеру як доброзичливість, толерантність, активність.

Обладнання заняття: відеофрагменти, відеоролики, аудіозаписи, комп'ютер, роздруківки з навчального зошита, роздавальний матеріал.

\section{Хід заняття}

1. Організаційний момент (2 хв.).

повідомлення теми та цілей заняття.

2. Мовленнєва зарядка. Актуалізація теми заняття (3 хв.).

3. Аудіювання тексту "Is There An American Dream?" (15 хв.).

- формулювання інструкції (1 хв.);

- презентація аудіоматеріалу (4 хв.);

- контроль розуміння прослуханого (3 хв.);

- виконання післятекстових завдань (2 хв.);

- обговорення тексту в режимі нон-стоп (5 хв.).

4. Перегляд короткого відеоролику 'Why the American Dream is a Myth?'. Дискусія. (10 хв.).

5. Робота з текстом "The American Dream" (15 хв.).

- відповіді на запитання;

- робота в мікрогрупах;

- виконання післятекстових завдань.

6. Перегляд відеофрагменту промови видатного політичного діяча - Мартіна Лютера Кінга "I Have A Dream" із подальшим його обговоренням (15 хв.).

- формулювання інструкції (2 хв.);

- презентація відеоматеріалу (6 хв.);

- контроль розуміння переглянутого та прослуханого (7 хв.);

6. Розвиток монологічного мовлення. Обговорення цитат про 'мрії' видатних англійських, американських та ірландських авторів (10 хв.). 
8. Прослуховування та читання напам'ять вірша Едгара Аллана По "A Dream Within A Dream" (8 хв.).

9. Підведення підсумків заняття. Надання методичних рекомендацій щодо виконання домашнього завдання. Оцінювання знань студентів (2 хв.).

\section{Методичне забезпечення}

Global Upper-Intermediate Coursebook / ed. by Lindsay Clandfield and Rebecca Robb Benne with additional material by Amanda Jeffries. Maccmillan, 2015. - 160 p.

Global Upper-Intermediate Workbook / ed. by Robert Campbell and Adrian Tennant. - Maccmillan, 2015. - $96 \mathrm{p}$.

Edgar Allan Poe "A Dream Within A Dream". [Електронний ресурс]. - Режим доступу: https: // www.edgarpoe.ru>a-dream-within-a-dream

Martin Luther King, Jr. "I Have A Dream" Speech, August 28, 1963. - [Електронний ресурс]. - Режим доступу: https: www.youtube. $\mathrm{com} /$ watch?v=vP4iY1TtS3s

What students are saying about the American Dream? - The New York Times, February 14, 2019. - [Електронний ресурс]. - Режим доступу: https: //www.nytimes.com/2019/02/14/

Why the American Dream is a Myth? - [Електронний ресурс]. - Режим доступу: https://www. youtube.com/watch\%3Fv\%3DTPcmCpbiDiw

\section{Розгорнутий план-конспект заняття}

Етап 1. Початок заняття. Повідомлення теми та цілей заняття.

Teacher: Dear ladies! I am happy to greet you at our English lesson. I was looking forward to meeting you today, you know why, don't you? Are you ready to start our lesson? OK, let's start then. Today we're going to speak about the dream, what people usually mean when they talk about the dream. We'll discuss what the American Dream is, extend our vocabulary using quotations about dreams, and practice 'conditional structures, real and unreal conditionals, wishes and regrets' in the process of communication on the given topic.

\section{Етап 2. Мовленнєва зарядка.}

Teacher: l'd like to start our topic with a discussion. Imagine you hear someone say the following sentence: "I'm living the American Dream!" Share your ideas with your partner.

Режим роботи: $S_{1}-S_{2}, S_{3}-S_{4}$ i т.п.
Suggested answers.

$\mathrm{S}_{1}$ : The American Dream exists; it is possible to live the American Dream when you are rich.

$\mathrm{S}_{2}$ : I think that the American Dream is a myth. It's impossible to achieve. Most people cannot achieve the American Dream, even if they work hard.

$\mathrm{S}_{3}$ : I think the American Dream is a great idea. Providing you work hard and really want something, then you will get it. You can be anybody you want to be, you just have to want it enough.

Етап 3. Аудіювання тексту "Is There An American Dream?"

1) формулювання інструкції;

2) презентація аудіоматеріалу;

3) контроль розуміння прослуханого;

4) виконання післятекстових завдань;

5) обговорення тексту в режимі нон-стоп.

Робота з навчальним посібником Global Upper-Intermediate Coursebook, p. 90.

Teacher: Listen to seven Americans and answer the question 'Is there an American Dream?' If so, what is it? Which speakers are optimistic about the American Dream? Which are pessimistic?

\section{Режим роботи: T-Ss.}

\section{Audioscript}

Speaker 1. The American Dream exists; it is possible to live the American Dream ... as long as you have lots of money.

Speaker 2. I consider the American Dream is a great idea. Erm, basically it says that, providing you work hard and really want something then you will get it. You can be anybody you want to be, you just have to want it enough.

Speaker 3. Isn't it a dream that most people in this country have - to live a better life than their parents did? That's what I always heard. I think it's a bit of an illusion - just an idea that people carry in their minds. Many people today would argue that their lives are, in fact, not as good as their parents' lives.

Speaker 4. Make more money. Have more expensive things. Buy more cars. Buy bigger houses. Don't think about tomorrow. Don't have any free time because you're always working. That's living the American Dream, in my mind.

Speaker 5. My family were immigrants to this country, and they always had this idea fixed in their heads that things would be better for their 
children because this is America. And they were right. As long as you work hard, and teach your children right, then things can get better for them. It's a good idea for a society.

Speaker 6. We need a new American Dream, because unless we stop buying and consuming and polluting so much we're going to destroy the environment that makes the American Dream worth living. I think we need dream that focuses on a more simple life and less on making money all the time.

Speaker 7. I have a suspicion, at the back of my mind, that the American Dream is a myth. It's impossible to achieve but it keeps people busy. Most people cannot achieve the American Dream, even if they work very hard.

(Students' suggested answers: Speakers 2 and 5 are optimistic. Speakers 3, 4, 6 and 7 are pessimistic. Speakers 1's comments are ambiguous - the speaker implies that the American Dream is a good thing but it is only possible if you are rich).

Teacher: Listen a second time and match each speaker to an opinion below. Complete the matching task. Check in pairs before feedback.

Режим роботи:T- $\mathrm{S}_{1}-\mathrm{S}_{2}, \mathrm{~S}_{3}-\mathrm{S}_{4}$ i т.п.

1) People chase the American Dream but they never get it.

2) _ People's lives now are not as good as in the past.

3) The American Dream is a good idea for parents to teach their children.

4) _ We need to take care of the environment and stop consuming so much.

5) __ Work hard, play hard and buy lots of things.

6) __ You can be anyone and do anything you want.

7) You have to be rich to live the dream.

Suggested answers:

1. Speaker 7;

2. Speaker 3;

3. Speaker 5;

4. Speaker 6;

5. Speaker 4;

6. Speaker 2;

7. Speaker 1.

Teacher: Work in pairs. Choose two of the groups of questions to discuss.

Режим роботи:T- $S_{1}-S_{2}, S_{3}-S_{4}$ i т.п.
1. Is it enough to work hard and want something to get it? If not, what other factors are important?

2. One speaker mentions a 'dream of a simple life'. What kind of life do you think that would be?

3. Is the idea of 'the American Dream' unique to America? Why? / Why not?

4. Could this be the national dream in your country? In any other countries?

5. Is it a good idea for a country to have a national dream?

Етап 4. Перегляд короткого відеоролику 'Why the American Dream is a Myth?' Дискусія.

Teacher: Формулювання інструкції:

You are going to watch a 2-minute video 'Why the American Dream is a Myth?' Compare and contrast your ideas.

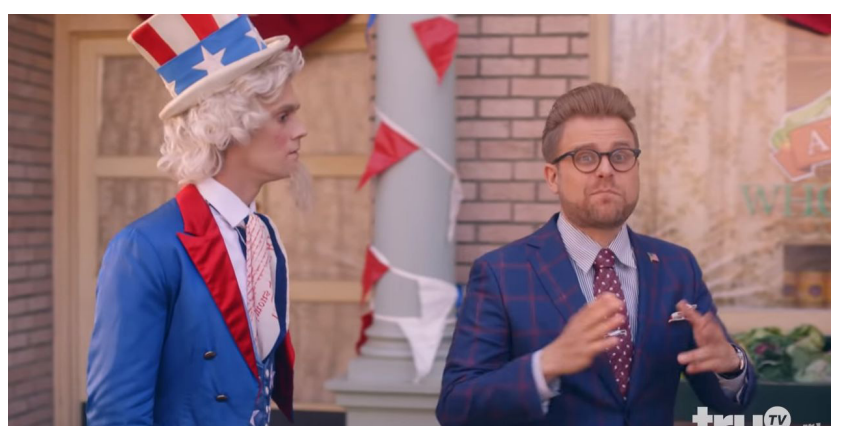

Режим доступу: https://www.youtube.com/ watch\%3Fv\%3DTPcmCpbiDiw

1) Is the American Dream a Myth?

2) Why the American Dream is a Myth? Explain.

Режим роботи: T-S $-\mathrm{S}_{2}-\mathrm{S}_{3}-\mathrm{S}_{4} ; \mathrm{S}_{1}-\mathrm{S}_{2}, \mathrm{~S}_{3}-\mathrm{S}_{4}$ i т.п.

Етап 5. Робота 3 текстом 'The American Dream'.

Skim Reading Tasks: Read the text and find out how Adams described 'The American Dream' in 1931. Clarify the words stature (n), capable (adj.) and regardless (adv.) in context.

\section{А. Виконання передтекстового завдання. Режим роботи: $\mathrm{S}_{1}-\mathrm{S}_{2}, \mathrm{~S}_{3}-\mathrm{S}_{4}$ i т.п.}

Answer the questions with a partner (Suggested answers).

1) What do you know about first use of American Dream? 
2) Is the idea of 'the American Dream' unique to America? Why?/Why not?

3) Is it a good idea for the country to have a national dream?

\section{The American Dream}

The American Dream is the dream of a land in which life should be better and richer and fuller for everyone, with opportunity for each according to ability or achievement... It is not a dream of motor cars and high wages merely, but a dream of social order in which each man and each woman shall be able to attain to the fullest statute of which they are innately capable, and be recognized by others for what they are, regardless of the fortuitous circumstances of birth or position.

Traditionally, we think of the American Dream as owing a home and having a happy family, with some undefined financial success often referred to as 'comfortable and high-standard living'. The dream aspect of the American Dream, however, connotes a traditional and national vision, despite some of the mundane aspects of the dream as it is often defined.

The American Dream that has lured tens of millions of all nations to our shores in past century has not been a dream of merely material plenty, though that has doubtless counted heavily. It has been much more than that. It has been a dream of being able to grow to fullest development as man and woman, unhampered by the barriers, which had slowly been erected in older civilizations, unrepressed by social orders which had developed for the benefit of any and every class.

And that dream has been realized more fully in actual life here than anywhere else. Despite the fact that 'the American Dream' has been often deconstructed and sometimes attacked as the dream of a white and male-centered European culture, we offer insights as to how the concept of the American Dream was born during American history.

James Truslow Adams, the Epic of America (1931)

\section{Glossary}

fortuitous (adj.) - lucky; mundane (adj.) worldly, ordinary; to attain (v) - reach; to lure (v) - tempt; unhampered (adj.) - not delayed, unhindered.
В. Виконання післятекстих завдань.

Режим роботи: $S_{1}-S_{2}-S_{3}-S_{4}$ (робота у мікрогрупах).

Task 1. Перевірка розуміння основного змісту тексту за допомогою питань про основні фокти.

Answer the questions.

1) In your own words, what do you think the author means?

2) Do you think this is a good dream?

3) Is this what people usually mean when they talk about the American Dream?

4) Is this book a must for students of American history and American literature? Express your ideas.

Task 2. Перевірка вмінь орієнтуватися в прочитаному тексті за допомогою завдань на пошук певної інформації:

Teacher: Find as quickly as possible and read ...

Give laconic answers to ...

Режим роботи: $\mathrm{S}_{1}-\mathrm{S}_{2}, \mathrm{~S}_{3}-\mathrm{S}_{4}$ і т.п.

Етап 6. Презентація відеоматеріалу. Перегляд відеофрагменту промови видатного політичного діяча - Мартіна Лютера Кінга "I Have A Dream" із подальшим його обговоренням.

A. Формулювання інструкції:

You are going to watch an emotionally persuasive Dr. King's appeal in which he describes the dream of human dignity and mutual toleration and love that is expressed in both the legal and the sentimental documents of the United States. The argument he builds from needs no further proof; but the social implication of that argument, he reminds us, need yet to be realized.

Teacher: Коротко розповідає про Мартіна Лютера Кінга. Нижче подається уривок з тексту відео.

Режим роботи: $\mathrm{T}_{-} \mathrm{S}_{1}-\mathrm{S}_{2}, \mathrm{~S}_{3}-\mathrm{S}_{4}$ i т.п.

Martin Luther King, Jr.

\section{HAVE A DREAM}

On August 28, 1963, a quarter of a million people of all races marches on Washin-gton, D.C., in a civil rights demonstration. This March for Freedom culminated at the Lincoln Memorial, where leaders of the civil rights movement spoke the hopes of most Americans. It was Dr. Martin 
Luther King, Jr. (1929-1968), however, who made the most eloquent statement of the Negroes' dreams and aspirations. Seven years before, he rose to international prominence as organizer of the year-long boycott of the local bus companies in Montgomery, Alabama, which ended in the desegregation of the buses. The year after the march on Washington, Dr. King receives the Nobel Prize for Peace. In his last speech he said, "I've seen the promised land", but added, "I may not get there with you". The next day, April 4, 1968, in Memphis, he was assassinated.

\section{Б. Презентація відеоматеріалу:}

Teacher: Watch the video and take notes on the speaker attempts to move his audience through his use of words and their arrangement. Pay attention to repetition of phrases; the emphatic repetition of a single word; alliteration; figurative language; and appeal to the emotions and the imaginations, as well as to the intellect.

Режим роботи: $\mathrm{T}_{-} \mathrm{S}_{1}-\mathrm{S}_{2}, \mathrm{~S}_{3}-\mathrm{S}_{4}$ i т.п.

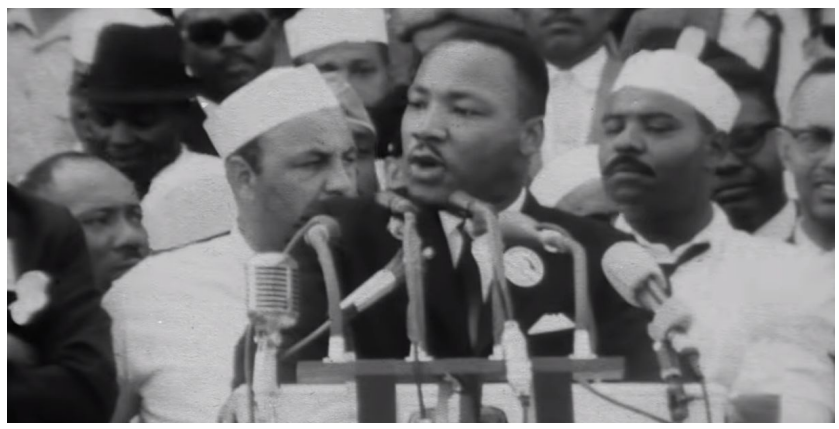

Режим доступу: https: www.youtube.com/ watch?v=vP4iY1TtS3s

[1] I am happy to join you today in what will go down in history as the greatest demonstration for freedom in the history of our nation.

[2] Five score years ago, a great American, in whose symbolic shadow we stand today, signed the Emancipation Proclamation. This momentous decree came as a great beacon light of hope to millions of Negro slaves who had been seared in the flames of withering injustice... But one hundred years later, the Negro still is not free. One hundred years later, the life of the Negro is still sadly crippled by the manacles of segregation and the chains of discrimination. One hundred years later, the Negro lives on a lonely island of poverty in the mildst of a vast ocean of the material prosperity. One hundred years later, the Negro is still anguished in the corners of
American society and finds himself in exile in his own land. And so we have come here today to dramatize a shameful condition...

[11] I say to you today, my friends, even though we face the difficulties of today and tomorrow, I still have a dream. It is a dream deeply rooted in the American dream. I have a dream that one day this nation will rise up and live out the true meaning of its creed: "We hold these truths to be self-evident, that all men are created equal". I have a dream that one day, on the red hill of Georgia, sons of former slaves and the sons of former slave owners will be able to sit down together at the table of brotherhood. I have a dream that one day even the state of Mississipi, a state sweltering with the heat of injustice, sweltering with the heat of oppression, will be transformed into an oasis of freedom and justice. I have a dream that my four little children will one day live in a nation where they will not be judged by the color of their skin, but by the content of their character.

[12] I have a dream today. I have a dream that one day down in Alabama - with its vicious racists, with its governor's lips dripping with the words of interposition and nullification - one day right there in Alabama, little Black boys and Black girls will be able to join hands with little white boys and white girls as sisters and brothers.

[13] I have a dream today. I have a dream that one day every valley shall be exalted and every hill and mountain shall be made low, the rough places will be made plain and the crooked places will be made straight, and the glory of the Lord shall be revealed, and the flesh shall see it together.

[14] This is our hope. This is the faith...

\section{В. Контроль розуміння переглянутого та} прослуханого:

Teacher: What is the most important feature of an emotional speech? What makes Dr. King a prominent speaker? What attempts does the speaker use to move his audience through his use of words and their arrangement?

Define the following words as they are used in the selection: sear (adj.), to cripple (v), to assassinate $(v)$, segregation $(n)$, to anguish $(v)$, creed $(n)$, to swelter ( $v$ ), dripping (adj.), nullification (n).

Dr. King makes much use of adjectives to communicate emotion. In Paragraph 2, the evocative adjectives are great (used twice), symbolic, 
momentous, withering, and joyous. What further examples of evocative adjectives do you find?

Dr. King quotes from and alludes to several famous American documents. What is the effect of these references and allusions? What is the basis of their appeal?

What, specifically, is the argumentative content of the speech? What is Dr. King advising his listeners to do?

Режим роботи: $\mathrm{T}_{-} \mathrm{S}_{1}-\mathrm{S}_{2}, \mathrm{~S}_{3}-\mathrm{S}_{4}$ і т.п.

(Students' answers).

Етап 7. Розвиток монологічного мовлення. Обговорення цитат про 'мрії' видатних англійських, американських та ірландських авторів.

Teacher: Listen to the following quotations about dreams by four writers. Repeat the quotations. For each quotation discuss with a partner what you think it means and what sort of dreams they are talking about. Which quotations do you like the best?

1. 'The supreme object of life is to live. Few people live. It is true life only to realize one's own perfection, to make one's every dream reality'. Oscar Wilde

2. 'I have dreamed in my life, dreams that have stayed with me ever after, and changed my ideas; they have gone through and through me, like wine through water, and altered the color of my mind'. Emily Bronte

3. 'You see things; and you say, "Why?" But I dream things that never were; and I say, "Why not?"' George Bernard Show

4. 'Dreaming is an act pure imagination, attesting in all men a creative power, which if it were available in walking, would make every man a Dante or Shakespeare". F.H. Hedge

Режим роботи: $S_{1}-S_{2}, S_{3}-S_{4}$ i т.п.

Етап 8. Прослуховування та читання напам'ять вірша Едгара Аллана По “A Dream Within A Dream". Робота над формуванням інтонаційних навичок.

Teacher:

Task 1. To pronounce words distinctly is an important skill for all of us. Read the biographical information about Edgar Allan Poe and listen to the poem "A Dream Within A Dream".

\section{Audioscript}

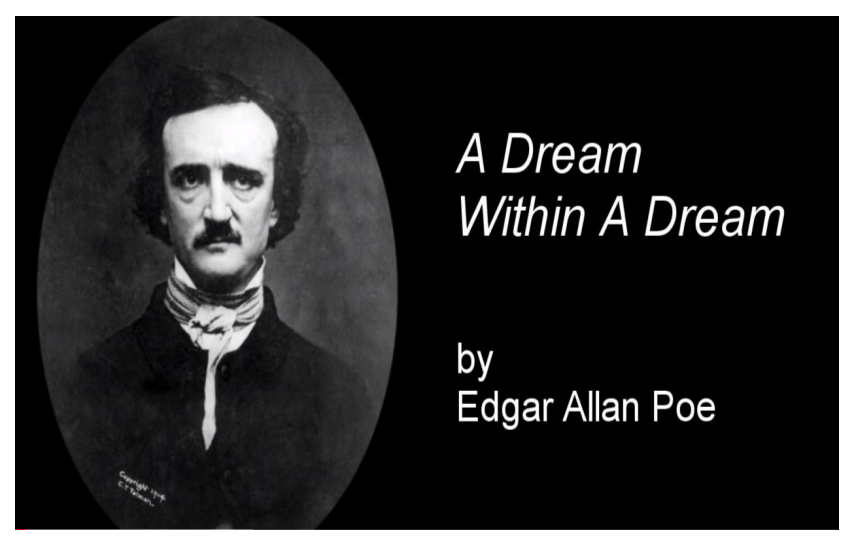

\section{A DREAM WITHIN A DREAM}

Take this kiss upon the bowl! And, in parting from you now, Thus much let me avow You are not wrong, who deem That my days have been a dream; Yet if hope has flown away In a night, or in a day, In a vision, or in none, Is it therefore the less gone? All that we see or seem Is but a dream within a dream.

I stand amid the roar Of a surf-tormented shore, And I hold within my hand Grains of the golden sand How few! yet how they creep Through my fingers to the deep, While I weep - While I weep!

O God! can I not grasp

Them with a tighter clasp?

O God! can I not save

One from the pitiless wave?

Is all that we see or seem

But a dream within a dream? Edgar Allan Poe

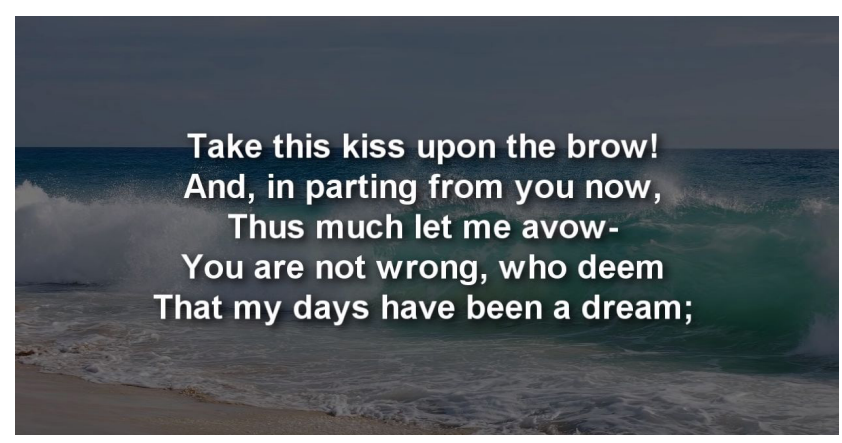

Teacher: Choose the best summary. Prove your points. 